\title{
GROUND GRAVITY MEASUREMENTS FROM GOLDSTREAM VALLEY, INTERIOR
}

\section{ALASKA}

Abraham M. Emond, Clark Jorgensen, Alec C. Lockett, Ronald P.Daanen, Gabriel J. Wolken, Katreen Wikstrom Jones, and Simone Montayne

Raw Data File 2020-10

This report has not been reviewed for technical content or for conformity to the editorial standards of DGGS.

2020

STATE OF ALASKA

DEPARTMENT OF NATURAL RESOURCES

DIVISION OF GEOLOGICAL \& GEOPHYSICAL SURVEYS
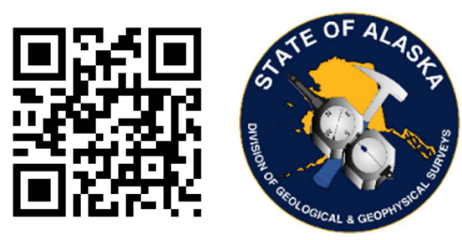


\section{STATE OF ALASKA}

Mike Dunleavy, Governor

\section{DEPARTMENT OF NATURAL RESOURCES}

Corri A. Feige, Commissioner

\section{DIVISION OF GEOLOGICAL \& GEOPHYSICAL SURVEYS}

Steve Masterman, State Geologist \& Director

Publications produced by the Division of Geological \& Geophysical Surveys are available to download from the DGGS website (dggs.alaska.gov). Publications on hard-copy or digital media can be examined or purchased in the Fairbanks office:

\section{Alaska Division of Geological \& Geophysical Surveys (DGGS)}

3354 College Road | Fairbanks, Alaska 99709-3707

Phone: 907.451.5010 | Fax 907.451.5050

dggspubs@alaska.gov $\mid$ dggs.alaska.gov

\section{DGGS publications are also available at:}

Alaska State Library, Historical

Collections \& Talking Book Center

395 Whittier Street

Juneau, Alaska 99801

Alaska Resource Library and

Information Services (ARLIS)

3150 C Street, Suite 100

Anchorage, Alaska 99503

\section{Suggested citation:}

Emond, A.M., Jorgensen, Clark, Lockett, A.C., Daanen, R.P., Wolken, G.J., Wikstrom Jones, Katreen, and Montayne, Simone, 2020, Ground gravity measurements from Goldstream Valley, interior Alaska: Alaska Division of Geological \& Geophysical Surveys Raw Data File 2020-10, 5 p. https://doi.org/10.14509/30473
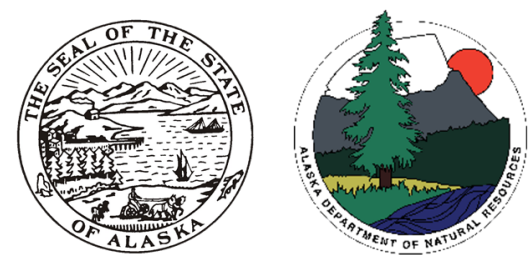


\section{GROUND GRAVITY MEASUREMENTS FROM GOLDSTREAM VALLEY, INTERIOR ALASKA} Abraham M. Emond', Clark Jorgensen², Alec C. Lockett', Ronald P. Daanen', Gabriel J. Wolken', Katreen Wikstrom Jones' ${ }^{1}$, and Simone Montayne ${ }^{1}$

\section{ABSTRACT}

The Goldstream Valley, located in Fairbanks, Alaska, is a semi-urban arctic watershed targeted for multidisciplinary investigations of interactions between permafrost, groundwater, surface hydrology, and biogeochemical cycles to understand the release of methane gas from degrading permafrost. To support concurrent research, Alaska Division of Geological \& Geophysical Surveys (DGGS) staff collected gravity measurements from 105 stations throughout the Goldstream Valley during 2017 and 2018 (fig. 1). These stations were collected to help determine the depth of fill in the Goldstream Valley. Bouguer anomaly maps were created of the study area. All files can be downloaded from the DGGS website: http://doi.org/10.14509/30473.

\section{DATA PRODUCTS}

The following digital products were produced for this project:

- Processed data in ASCII and Geosoft database formats

- Simple Bouguer gravity ${ }^{4}$ data and grids (fig. 2.)

- Complete Bouguer gravity ${ }^{5}$ data and grids (fig. 3)

\section{DATA ACQUISITION AND EDITING}

Data were collected on the ground using the LaCoste \& Romberg gravimeter number 507. The gravimeter was primarily transported by bicycle. Station coordinates were positioned using a real-time or post-processed corrected differential GPS. Data were tied to absolute gravity using U.S. Geological Survey (USGS) absolute gravity station Fairbanks C. Repeat readings were made for data quality (table 1). The data were examined and filtered to remove erroneous locations or readings.

\section{DATA PROCESSING}

The gravity data were reduced to the simple Bouguer anomaly values. This processing removes the effects of instrument drift, moon induced tides, latitude, and elevation. The values were calculated using a reduction density of 2.67 $\mathrm{g} / \mathrm{cm}^{3}$. Several stations were also collected on packed snow or ice. Estimated densities of packed snow or ice and their effects were also included in the processing.

\footnotetext{
${ }^{1}$ Alaska Division of Geological \& Geophysical Surveys, 3354 College Road, Fairbanks, AK 99709

${ }^{2}$ Big Sky Geophysics, P.O. Box 353, Bozeman, MT 59771

${ }^{3}$ Colorado College, Department of Geology, 14 East Cachela Poudre St., Colorado Springs, CO 80903

${ }^{4}$ Simple Bougeur gravity = station gravity - latitutde correction + free-air elevation correction - Bouguer slab correction

${ }^{5}$ Complete Bouguer gravity = station gravity - latitutde correction + free-air elevation correction - Bouguer slab correction - terrain corrections
} 
Terrain corrections were applied to a distance of $166.7 \mathrm{~km}$ using Alan Cogbill's algorithm (Cogbill, 1990) and digital terrain models derived from radar altimeter data (table 2). $166.7 \mathrm{~km}$ is the distance at which the effect of the earth's curvature has a greater influence than the effect of terrain for most places on earth. No earth curvature corrections were applied. After applying these corrections, remaining contrasts in the gravimetric response are caused by geology. Cogbill's algorithm creates a smooth surface using a multi-polynomial formula for the inner terrain correction and simple blocks for the outer terrain correction. The complete Bouguer anomaly was calculated by adding the simple Bouguer gravity and all the terrain corrections.

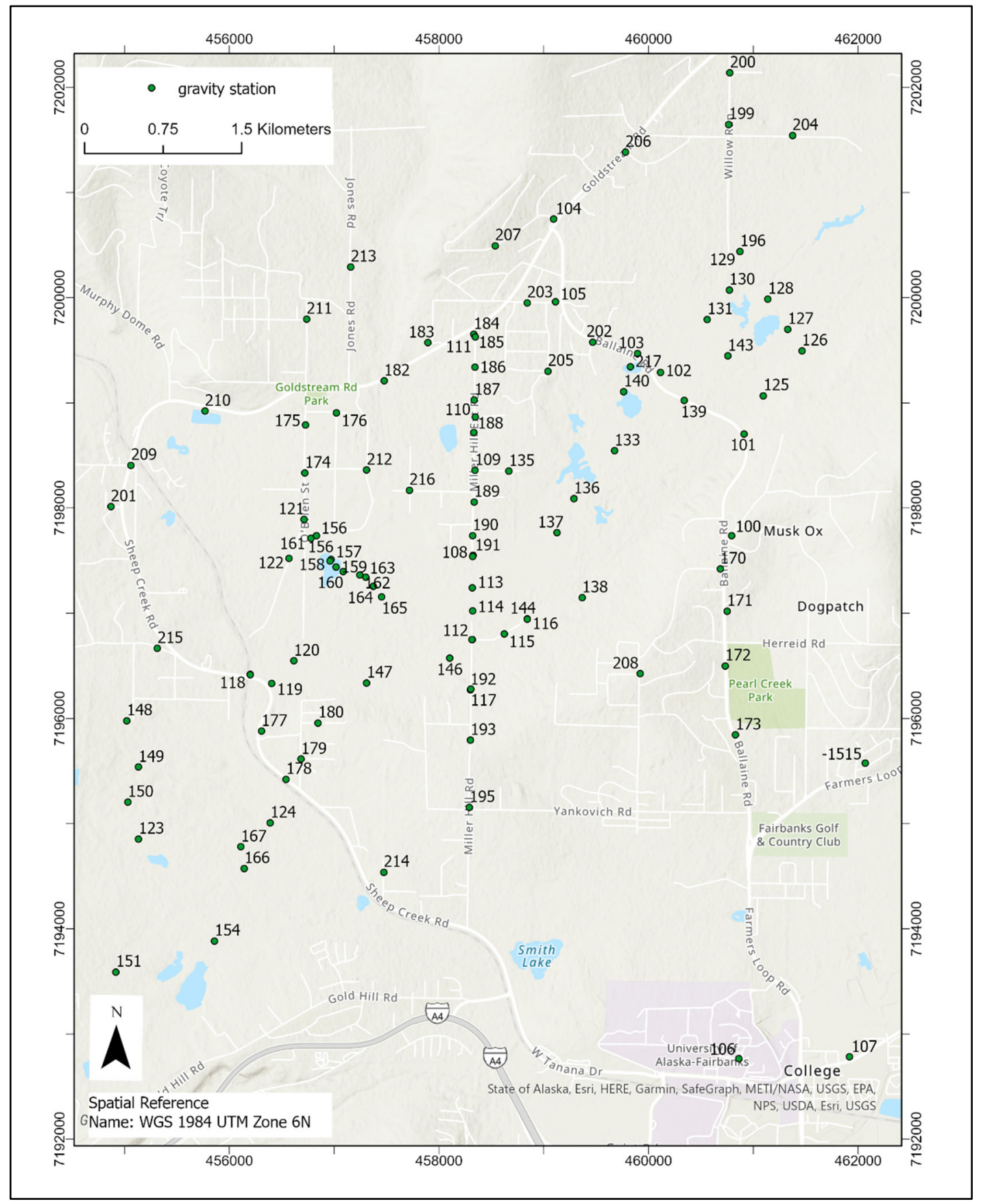

Figure 1. Map showing gravity station locations and nearby roads. 
Raw Data File 2020-10

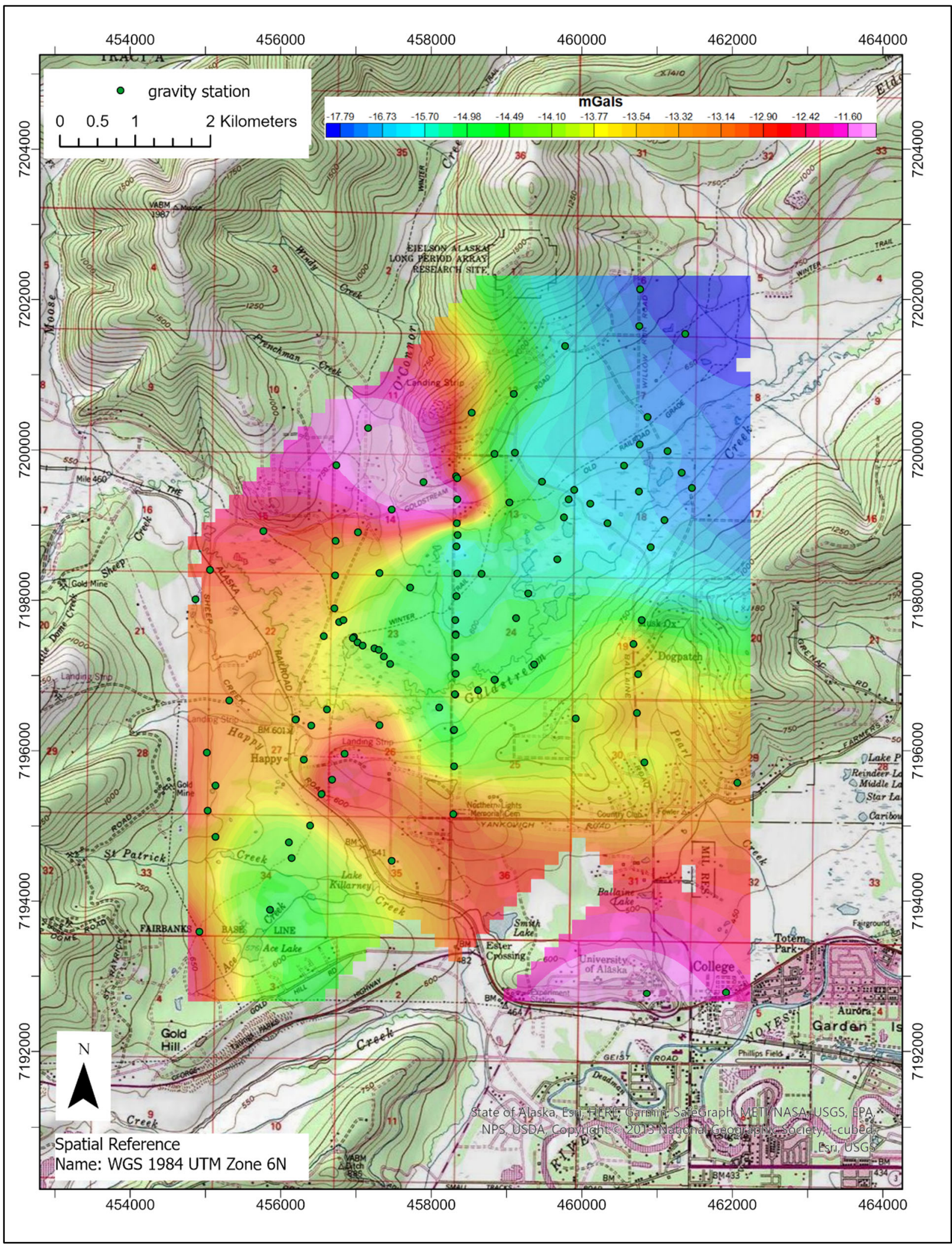

Figure 2. Preview of the simple bouguer anomaly grid, station locations, and UTM grid. Maps, grids, and point data are available in the digital data distribution package of this report. 




Figure 3. Preview of the complete bouguer anomaly grid, station locations, and UTM grid. Maps, grids, and point data are available in the digital data distribution package of this report. 
Table 1. Repeated stations.

\begin{tabular}{|l|c|c|}
\hline Station Name & Reading count & $\begin{array}{l}\text { Range } \\
\text { in } \\
\text { mGal }\end{array}$ \\
\hline mhr & 10 & 0.07 \\
\hline sheeprr & 9 & 0.28 \\
\hline balaineppull & 5 & 0.09 \\
\hline 1515correct & 4 & 0.09 \\
\hline fairbanks-c & 4 & 0.04 \\
\hline mailbox2080 & 4 & 0.08 \\
\hline dggs-E-20170 & 3 & 0.02 \\
\hline rr00 & 3 & 0.22 \\
\hline rr013a & 3 & 0.02 \\
\hline vollata & 3 & 0.04 \\
\hline 2243 & 2 & 0.19 \\
\hline chili & 2 & 0.07 \\
\hline dl001 & 2 & 0.01 \\
\hline eldorado & 2 & 0.08 \\
\hline gsv010 & 2 & 0.02 \\
\hline gsvw06 & 2 & 0.42 \\
\hline gsvw10 & 2 & 0.04 \\
\hline mhex01 & 2 & 0.03 \\
\hline
\end{tabular}

Table 2. Distance, digital terrain model, and the algorithm used to calculate terrain corrections.

\begin{tabular}{|l|l|l|}
\hline Distance & Digital terrain model & Algorithm \\
\hline $\mathbf{5 m - 1 , 5 0 0 m}$ & $5 \mathrm{~m}$ radar grid & Cogbill algorithm, smooth integrated surface \\
\hline $\mathbf{1 , 5 0 0 m}-\mathbf{3 k m}$ & $30 \mathrm{~m}$ radar grid & Cogbill algorithm, smooth integrated surface \\
\hline $\mathbf{3 k m}-\mathbf{1 4 k m}$ & $30 \mathrm{~m}$ radar grid & Cogbill algorithm, flat-topped prisms \\
\hline $\mathbf{1 4 k m}-\mathbf{1 6 6 . 7 k m}$ & 30 -arcsecond grid & Cogbill algorithm, flat-topped prisms \\
\hline
\end{tabular}

\section{ACKNOWLEDGMENTS}

The Goldstream Valley Watershed project was funded by the National Science Foundation, Office of Polar Programs, Arctic System Science Program, award number 1500931.

\section{REFERENCES}

Cogbill, A.H., 1990, Gravity terrain corrections calculated using digital elevation models, Geophysics, v. 55, n. 1, p. 102-106. http://doi.org/10.1190/1.1442762

Emond, A.M., Daanen, R.P., Graham, G.R.C., Walter Anthony, Katey, Liljedahl, A.K., Minsley, B.J., Barnes, D.L., Romanovsky, V.E., and CGG Canada Services Ltd., 2018, Airborne electromagnetic and magnetic survey, Goldstream Creek watershed, interior Alaska: Alaska Division of Geological \& Geophysical Surveys Geophysical Report 2016-5, 14 p. http://doi.org/10.14509/29681 